\author{
文献 \\ 1) 西谷邦蜼, 日立評論 46, 97 (1964). \\ 2) 西谷邦堆，コンデンサ評諭 18，664 (1965).

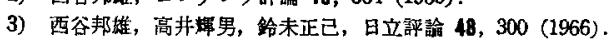 \\ 4) J. Vergnolle, J. Electrochem. Soc. 111, 799 (1964). \\ 5) J.W.A. Scholte, W. Ch van Geel. Philips Res. Repts. \\ 8. 47 (1953). \\ 6) Y. Sasaki, J. Phys. Chem. Solids. 13, 177 (1960).
}

7) A.P. Belova, L.C. Gorskaya, L.N. Zakgeim, Soviet Phys-Solid State, 2, 1348 (1961).

8) M.A. Heine \& M.J. Pryor, J. Electrochem. Soc. 110, 1205 (1963).

9）西谷邦婎，電気化学協会第 29 回大会腾演要昌集 143 (1962).

10) J.P. Cuevillot et, J. Brenet, Compt. Rend. 249, 1869 (1959).

11）西谷邦雄，本誌 36，7 月号揭載予定.

\title{
Boehmite 皮膜の構造および生長機 構*
}

\author{
The Structure and Formation Mechanism of Boehmite \\ Michiko SHIMURA and Sakae TAJIMA \\ (Tokyo Metropolitan University, 2-Fukazawa, Setagaya-ku, Tokyo)
}

志村美知子**, 田島栄**

The structure of aluminium oxide films formed in electric field-free conditions is discussed as a part of the anodic oxidation of aluminium.

In this paper, discussions are exclusively on oxide films chemically formed in hot water.

99.9 and $99.99 \% \mathrm{Al}$ specimens were pre-treated and dipped in baths of distilled water, $0.1 \mathrm{~N}$ ammonia, and $0.1 \mathrm{~N}$-triethanolamine recommened by Altenpohl, to form conversion films.

The chemically formed films were examined by electron diffraction, electron-microscopy, measurement of weight changes (either by balance or photoelectric colorimeter), and impedance measurement.

A local electric field induced across the thin film between local anodes of the metal and the solution causes ions to migrate through the film resulting in a growth of boehmite.

Boehmite growth is closely related with the amount of $\mathrm{OH}^{-}$ion in the bath.

It is demonstrated that the $\mathrm{OH}^{-}$ion plays many important roles, i.e. it is not only the reactant in the equation $\mathrm{Al}^{3+}+2 \mathrm{OH}^{-} \rightarrow \mathrm{Al} \cdot \mathrm{O} \cdot \mathrm{OH}+\mathrm{H}^{+}$but also the electric field inducer to promote the migration of $\mathrm{Al}^{3+}+$ ion through the film and the neutralizer of $\mathrm{H}^{+}$ion produced during the boehmite growth.

However, since the excess $\mathrm{OH}^{-}$ion induces the corrosion of boehmite, an optimum condition for boehmite growth exists at a certain concentration of $\mathrm{OH}^{-}$ion.

$0.1 \mathrm{~N}$-ammonia solution is recommended, since it contains sufficient $\mathrm{OH}^{-}$ion to form boehmite quickly but does not cause appreciable film corrosion owing to the gradual evaporation of $\mathrm{NH}_{3}$ during the formation.

\section{1 緒 富}

アルミニウム上には陽極酸化によらないでも，かなり 檿い防食性皮膜を純化学処理によって生成させることが できる(1),2). これらのうちいわゆる Boehmite 皮膜は 打孔に $\gamma-\mathrm{Al} \cdot \mathrm{O} \cdot \mathrm{OH}$ から成り, 水による一種の腐食反 応で最も基本的なものであるが，同時にアルミニウムに 対するすぐれた防護皮膜となる.これの生成条件につい ては特に Altenpohl の研究が著名である. 本報は, Boehmite 皮膜の構造, 生成機構を明らかにしたもので ある。

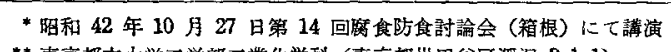

** 東京都立大学工学部工業化学科 (東京都世田谷区深沢 2-1-1)

\section{2 実験方法}

\section{1 電子線回折}

化学化成皮膜に対しては, X 線回折法は透過力が強く 不適当と考えられるので電子線回折反射洗を用いた。

試料は純度 99.996 および $99.99 \%$ の種のアルミニ ウム板であって, 次の順に前処理を行なった。

まずトルエンで脱脂しアルコールと水で洗浄し, 次に リン酸系浴にて電解研摩*1したのち, 化学化成に用いる まで一旦デシケータ内に保存する．その後化成直前にお レてリン酸,クロム酸による皮膜はく離*を行なう。これ

*1 浴租成: リン酸 $700 \mathrm{cc}$, 硫酸 $200 \mathrm{cc}$, ク口ム酸 $80 \mathrm{~g}$, 水 $100 \mathrm{cc}$, 浴 温 $80 \sim 85^{\circ} \mathrm{C}, \mathrm{C} . \mathrm{D}:$ 約 $20 \mathrm{~A} / \mathrm{dm}^{2}$, 電解時間 3 分 
は電解研摩による陽極皮膜を除去するための処理である が，得られた清浄面の污染（自然酸化皮膜がおおう）を 避けるために化成直前を選んだ.

化学化成浴は, Altenpohl” が推奖する浴，すなわち 蒸留水， $0.1 N$ アモニア水（本実験における $\mathrm{pH} \doteqdot$ 11), $0.1 N$ トリタノールアミン（本実験における $\mathrm{pH} \div 11$ )を用いた。

化成温度は $95 \sim 100^{\circ} \mathrm{C}$, 化成時閒は $0 \sim 60 \mathrm{~min}$ とした。 化成後の試料は小さく切り $(3 \times 3 \mathrm{~mm})$ ，表面反射に よる電子線回折を行なった。

回折環については Bragg の式が適用され $d_{h k l}=\lambda \cdot L / r$ により原子面間隔 $d$ を求めることができる.

実際の手続は，標準物質金の回折環の $r$ を実測し， $r \times d$ の積（ $d$ は A.S.T.M. カードより求める）を計算 L, $\lambda \cdot L$ 求める. 次に $\overline{\lambda \cdot L}$ を試料の回折環半径 $r$ で 割り， $d_{h k l}$ 莸求め, A.S.T.M diffraction card 老調心 物質構造を同定するのである.

\section{2 電子顕微鏡観察}

2.2.1 直接観察 皮膜を次の方法でアルミ素地から はく離して電子線透過観察を行なった.

皮膜表面に傷をつけ，50ㄷ のヨードメタノール液 に浸せきし金属部分がことごとく溶解したときに皮膜を 取り出して洗浄する.

$$
\begin{aligned}
& 2 \mathrm{Al}+6 \mathrm{CH}_{3} \mathrm{OH}=2 \mathrm{Al}\left(\mathrm{OCH}_{3}\right)_{3}+3 \mathrm{H}_{2} \\
& 2 \mathrm{Al}+3 \mathrm{I}_{2}=2 \mathrm{AlI}_{3} \text { または }\left[2 \mathrm{Al}^{3+}+6 \mathrm{I}^{--}\right]
\end{aligned}
$$

ところが直接観察法には後述のような難点が見いだされ たので，二段レプリカ法に変更した。

2.2.2 二段レプリカ法 半溶解のアセチルセルロー ス板に皮膜表面の形をうつした後，真空内で $\mathrm{Cr}\left(45^{\circ}\right.$ 方

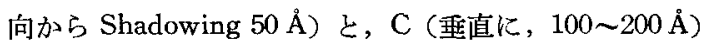
を蒸着させて蒸着膜を作る，その後アセチルセルロース 板のみを溶剤に溶かす，得られた蒸着膜を透過観察す る.
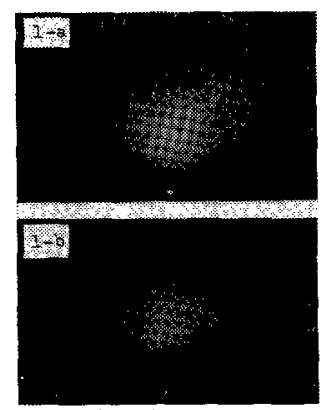

I-a : halo only

$1-\mathrm{b}$ : diffraction rings visible

$$
\text { Photo. } 1
$$

Electron diffraction pattern of metal surface immediately after pretraeted.
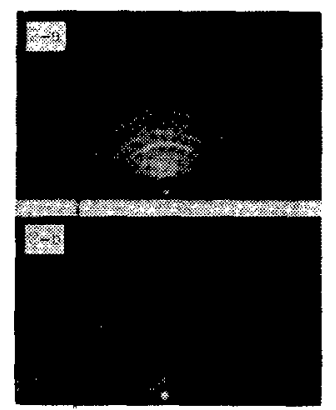

$2-\mathrm{a}$ : formation time, $10 \mathrm{~min}$ 2-b : $20 \mathrm{~min}$

Photo. 2

Electron diffraction pattern of films formed in $0.1 \mathrm{~N}-$ ammonia bath.

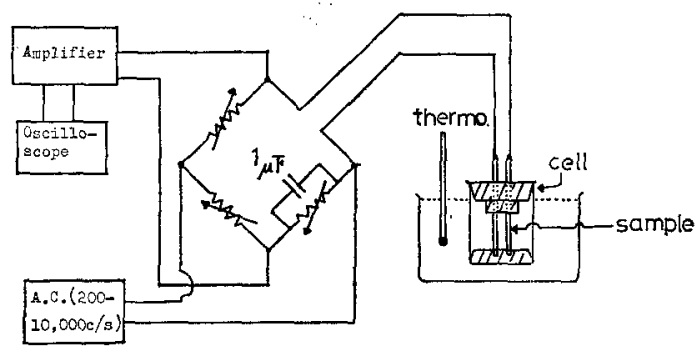

Fig. 1 Diagram for impedance measurement

2.3.1 皮膜溶解量の測定 化成前後の試料重量をひ 上5量し，化成時間による重量増減を求めた。

\section{4 比色法 ${ }^{5}$}

化成浴中に溶出する $\mathrm{Al}^{3+}$ 量を次のような比色分析法 で測定した。

化成浴に $1 \%$ オキシン・酶酸液を加え，2N-酢酸液を 滴下して pH 5.0 5.5 亿調整し(pHメーター使用)， 一定量のクロロフォルム中に $\mathrm{Al} ・$ オシン錯塩を抽出す る. 抽出液を硫酸ナトリウムで乾燥したのち「平間式」 光電比色計により波長 $420 \mathrm{~m} \mu$ の下で測定する.

\section{5 インピーダンス測定}

インピーダンスの測定は Bridge 法（横河製・万能プ リッジ使用)で行ない，試料 $(99.99 \%$ アルミ線， $\phi 1.71$ $\mathrm{mm}$ ，表面積 $5 \mathrm{~mm}^{2}$ ) を測定液中に二本対立させるやり 方をとった．周波数は $200 \sim 10,000 \mathrm{c} / \mathrm{s}$ とした．測定回 路扔よび測定セルを Fig. 1 亿示す.

測定液流 $3 \%$ 酒石酸アンモン水溶液 ${ }^{177} ， 1 N$ 食塩水 ${ }^{18\}}$ (ともに $25^{\circ} \mathrm{C}$ ) を用いた.

測定は化成後直ちに行ならこととし，水洗上同時に （乾燥せずに）供した。

\section{3 結果および考察}

\section{1 電子線回折}

前処理直後の「清浄な」金属表面については，6 視野
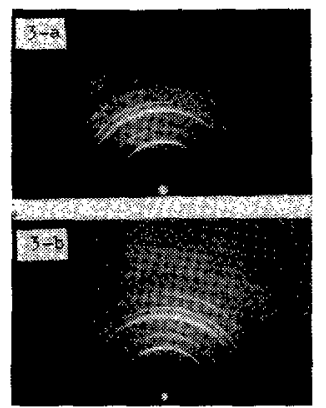

3-a : formation time, $10 \mathrm{~min}$ $3-b$ :

Photo. 3

Electron diffraction pattern of films formed in distilled water bath.

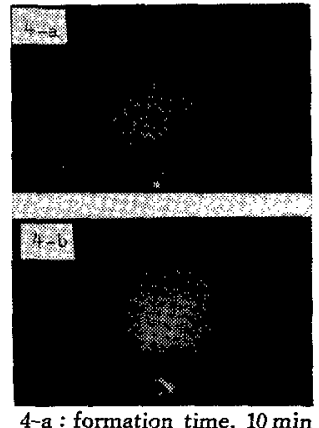

4-a: formation time, $10 \mathrm{~min}$

Photo. 4

Electron diffraction of pattern. films formed in $0.1 \mathrm{~N}$-trieth. anolamine bath.

* 浴温 $95^{\circ} \mathrm{C}$ 処理時間 3 分 
Table 1 Electron diffraction analysis of formed films

\begin{tabular}{|c|c|c|c|c|c|c|c|c|c|c|c|c|}
\hline \multirow{2}{*}{$\begin{array}{c}\text { Metal surface } \\
\text { immediately } \\
\text { after } \\
\text { pretreated. } \\
(d \AA)\end{array}$} & \multicolumn{3}{|c|}{ Al (from A.S.T.M.) } & \multicolumn{6}{|c|}{ Films formed in distilled water bath. $(d \dot{A})$} & \multicolumn{3}{|c|}{$\begin{array}{l}\text { Films formed in } 0.1 \mathrm{~N}- \\
\text { ammonia bath }(d \bar{A})\end{array}$} \\
\hline & $d \grave{\AA}$ & $I / I_{0}$ & bkl & $10 \mathrm{~min}$ & 20 & 30 & 40 & 50 & 60 & 5 & 10 & 20 \\
\hline \multirow[t]{2}{*}{$2.35 \mathrm{~m}$} & 2.338 & 100 & 111 & - & - & - & - & - & - & - & - & - \\
\hline & 2.024 & 47 & 200 & $3.13 \mathrm{w}$ & $3.21 \mathrm{w}$ & $3.12 \mathrm{w}$ & $3.14 \mathrm{~m}$ & $3.19 \mathrm{w}$ & $3.16 \mathrm{w}$ & $3.16 \mathrm{~s}$ & $3.16 \mathrm{~m}$ & $3.13 \mathrm{~m}$ \\
\hline $1.45 \mathrm{~m}$ & 1.431 & 22 & 220 & $2.34 \mathrm{~s}$ & $2.35 \mathrm{~s}$ & $2.33 \mathrm{~s}$ & $2.35 \mathrm{~s}$ & $2.32 \mathrm{~s}$ & $2.35 \mathrm{~s}$ & $2.34 \mathrm{~s}$ & $2.35 \mathrm{~s}$ & $2.34 \mathrm{~s}$ \\
\hline \multirow[t]{9}{*}{$1.23 \mathrm{~m}$} & 1.221 & 24 & 311 & $1.95 \mathrm{w}$ & $1.97 \mathrm{w}$ & $1.97 \mathrm{w}$ & $1.99 \mathrm{w}$ & $1.99 w$ & $1.98 \mathrm{w}$ & - & - & - \\
\hline & 1.169 & 7 & 222 & $1.85 \mathrm{~m}$ & $1.83 \mathrm{~s}$ & $1.83 \mathrm{~s}$ & $1.85 \mathrm{~s}$ & $1.84 \mathrm{~s}$ & $1.86 \mathrm{~m}$ & $1.86 \mathrm{~s}$ & $1.87 \mathrm{~s}$ & $1.85 \mathrm{~s}$ \\
\hline & 1.012 & 2 & 400 & $1.65 \mathrm{w}$ & $1.66 \mathrm{w}$ & $1.66 \mathrm{w}$ & $1.66 \mathrm{w}$ & $1.65 \mathrm{w}$ & $1.66 \mathrm{w}$ & $1.67 \mathrm{w}$ & $1.65 \mathrm{w}$ & $1.66 \mathrm{w}$ \\
\hline & 0.929 & 8 & 331 & - & - & - & - & - & $1.46 \mathrm{~s}$ & $1.46 \mathrm{~s}$ & - & - \\
\hline & 0.906 & 8 & 420 & $1.43 \mathrm{~s}$ & $1.43 \mathrm{~s}$ & $1.45 \mathrm{~s}$ & $1.45 \mathrm{~s}$ & $1.44 \mathrm{~s}$ & $1.44 \mathrm{~s}$ & - & $1.44 \mathrm{~s}$ & $1.43 \mathrm{~s}$ \\
\hline & 0.827 & 8 & 422 & - & -- & - & - & - & - & - & - & - \\
\hline & - & - & - & $1.30 \mathrm{~s}$ & $1.31 \mathrm{~s}$ & $1.32 \mathrm{~s}$ & $1.30 \mathrm{~s}$ & $1.31 \mathrm{~s}$ & $1.30 \mathrm{~m}$ & $1.32 \mathrm{~s}$ & $1.30 \mathrm{~s}$ & $1.31 \mathrm{~s}$ \\
\hline & - & - & - & - & - & - & $1.17 \mathrm{~s}$ & $1.17 \mathrm{w}$ & $1.16 \mathrm{w}$ & - & - & - \\
\hline & - & - & - & $1.11 \mathrm{~s}$ & $1.13 \mathrm{~s}$ & $1.04 \mathrm{~s}$ & $1.13 \mathrm{~s}$ & $1.13 \mathrm{~s}$ & $1.13 \mathrm{~m}$ & $1.14 \mathrm{~m}$ & $1.13 \mathrm{~m}$ & $1.14 \mathrm{~s}$ \\
\hline
\end{tabular}

観察した中で 5 視野がぼやけたハロー（Photo. 1-a) と なり, 唯一つの視野が Photo. 1-b のような回折環を示 した.この回折環から算出される面間隔は A.S.T.M. Card の Al の面間隔とほぼ同じとなったが，同時に アルミの酸化物や水酸化物 (Boehmite, Gibbsite, Bayerite*1) にる類似するために組成は確定されない (Table 1). 以上の結果加ら前処理直後の金属表面は金 属 $\mathrm{Al}$ ではなく, 過渡的な構造の酸化物の薄膜でお扔わ れていると考えられる。

化成皮膜については, 数本の鮮鋭な環の明確なパター ンが得られた (Photo. 2〜4).これらの面間隔はすべて A.S.T.M. Card $の$ Boehmite, すなわち $r-\mathrm{Al} \cdot \mathrm{O} \cdot \mathrm{OH}$ に一致した．面間隔を詳細に比較すると，化成浴によっ て多少相違 L, 最も標準値(A.S.T.M の Boehmite)に近 いの蒸留水化成皮膜であり，次いでアンモニア水，卜 リエタノールアミンの順になった. 蒸留水化成皮膜の回 折環は非常に鮮鋭で，他の化成皮膜では認めることので きない回折環 $\left(d_{131}=1,980 \AA\right)$ も確認された。一方トリ エタノールアミン化成皮膜では化成時間とともに回折像 が不鮮明になり，面間隔值が標準值からますますずれて 行く傾向がみられた.この浴では化成時間とともに， Boehmite が不安定になると考えられる. Boehmite の 安定域は $\mathrm{pH}$ 4〜11 1) なのでその上限付近では徐々に不 安定状態になる.水酸化ナトリウム浴の中では $\mathrm{pH}>9$ で不安定となり，Bayerite $\mathrm{Al}(\mathrm{OH})_{3}$ に移行する われている。

\section{2 電子顯微鏡観察}

3.2 .1 はく離皮膜観察 はく離皮膜の直接観察江不 鮮明 (Photo. 5・a〜c) となったため皮膜構造の検討は むずかしい，これの原因としては皮膜が一般に厚く電子 線不透過となりやすいことと，皮膜が元来応力を受けて いて丸まりやしわを作りやすいことにある。

後者の点の諭扰は以下の通りである。すなわち Boeh-

*1 Gibbsite $\mathrm{Al}_{2} \mathrm{O}_{3} \cdot 3 \mathrm{H}_{2} \mathrm{O}$ の面閏隔: $2.388,1.441,1.246,1.214$ Bayerite $\beta-\mathrm{Al}_{2} \mathrm{O}_{3} \cdot 3 \mathrm{H}_{2} \mathrm{O}$ " $: 2.36,1.445,1.257,1.211$

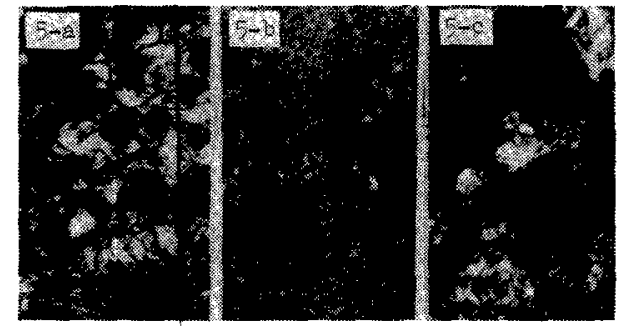

5-a : film formed in distilled water bath $(5 \mathrm{~min})$ $5-\mathrm{b}$ : film formed in distilled water bath $(15 \mathrm{~min})$ 5 -c : film formed in $0.1 N$-triethanolamine bath $(5 \mathrm{~min}$ )

Photo. 5 Electron micrographs of stripped films $(\times 20,000)$.

mite が生成するときに $\mathrm{Al} \rightarrow \mathrm{Al} \cdot \mathrm{O} \cdot \mathrm{OH}$ の変化による 体積増加は 1.76 2.00 倍*2になるべきである. しかし 金属上に生成するのであるから格子整合上金属 / Boehmite 界面の体積增加は抑制される. その結果 Boehmite 格子内には応力がかかるであるう。皮膜がはく離される とき㤎が解かれるから皮膜が丸まると考㝋られる。 た金属面には不純物や久陷があって皮膜の生長は均一に 行なわれないであろう。するとはく離されたとき発達が 良い部分がしわとなると考えられる。ささらにはく離操作 が不完全であれば，残存するアルミ粒子が一種の模様と なり，皮膜の本質を錯乱させてしまう。このような問題 により Boehmiteをはく㕍法によって観察することは好 ましくないと結論される。

3.2.2 レプリカ観察 レプリカ観察の結果は Photo. $6,7,8$ に見られるよらにはく離皮膜のときとはまったく 異なった外観が得られた。

まず蒸留水化成皮膜については，化成初期は一様な平 沿面 (Photo 6-a，b) となって扔り，化成経過とともに 複雑な凹凸面へ変化する (Photo. 6-c).これは(1) 式 $^{73}$,8) の Boehmite 生成で体積增加が起こりその余剩 分が極端に外側一突き出す結果凹凸化すると考えられ

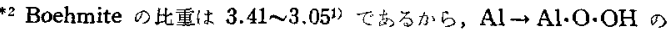
際の体積增加は $1.76 \sim 2.00$ となる. 


\begin{tabular}{|c|c|c|c|c|c|c|c|c|}
\hline \multicolumn{6}{|c|}{ Films formed in $0.1 \mathrm{~N}$-triethanolamine bath. } & \multicolumn{3}{|c|}{$\left(\begin{array}{c}\text { Boehmite } \\
\text { from } \\
\text { A.S.T.M. }\end{array}\right)$} \\
\hline $10 \mathrm{~min}$ & 20 & 30 & 40 & 50 & 60 & $d \dot{\mathrm{A}}$ & $l / I_{0}$ & hkl \\
\hline - & - & $\rightarrow$ & - & - & - & 6.11 & 100 & 20 \\
\hline $3.13 \mathrm{w}$ & $3.09 \mathrm{w}$ & $3.16 \mathrm{w}$ & $3.17 \mathrm{w}$ & $3.23 \mathrm{w}$ & $3.21 \mathrm{w}$ & 3.164 & 65 & $\left\{\begin{array}{l}21 \\
41\end{array}\right.$ \\
\hline $2.38 \mathrm{~s}$ & $2.34 \mathrm{~m}$ & $2.37 \mathrm{~s}$ & $2.37 \mathrm{~m}$ & $2.38 \mathrm{w}$ & $2.37 \mathrm{~m}$ & 2.346 & 53 & 130 \\
\hline - & - & - & - & - & - & 1.980 & 6 & 131 \\
\hline $1.85 \mathrm{~m}$ & $1.84 \mathrm{~m}$ & $1.87 \mathrm{~s}$ & $1.88 \mathrm{~s}$ & $1.89 \mathrm{~m}$ & $1.86 \mathrm{~m}$ & 1.860 & 32 & 150 \\
\hline $1.67 \mathrm{w}$ & $1.64 \mathrm{w}$ & $1.67 \mathrm{w}$ & $1.70 \mathrm{w}$ & - & - & 1.662 & 13 & 151 \\
\hline- & - & $1.46 \mathrm{~s}$ & $1.46 \mathrm{w}$ & $1.47 \mathrm{w}$ & $1.46 \mathrm{w}$ & 1.453 & 16 & 132 \\
\hline $1.43 \mathrm{~s}$ & $1.43 \mathrm{~s}$ & $1.43 \mathrm{w}$ & - & - & - & 1.434 & 9 & 200 \\
\hline- & - & $1.31 \mathrm{~s}$ & $1.32 \mathrm{w}$ & $1.32 \mathrm{w}$ & $1.31 \mathrm{w}$ & 1.312 & 15 & 152 \\
\hline $1.30 \mathrm{~m}$ & $1.29 \mathrm{~m}$ & - & - & - & - & 1.303 & 3 & 221 \\
\hline- & $\cdots$ & - & - & - & - & - & - & - \\
\hline $1.13 \mathrm{~m}$ & $1.12 \mathrm{~s}$ & $1.14 \mathrm{~s}$ & - & - & - & 1.134 & 5 & 202 \\
\hline
\end{tabular}

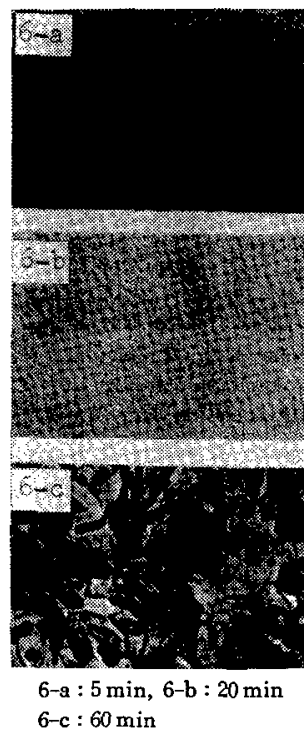

Photo. 6

Electron micrographs of two step replicas of films formed in distilled water bath $(\times 20,000)$.
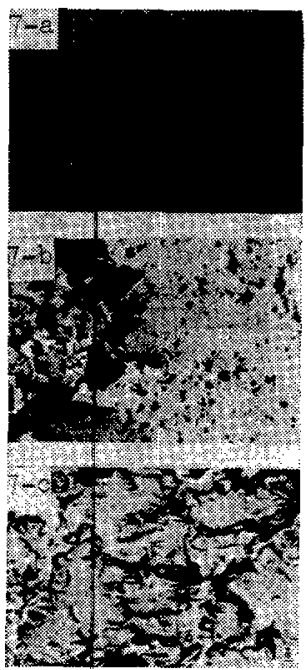

$7-\mathrm{a}: 1 \mathrm{~min}, 7-\mathrm{b}: 5 \mathrm{~min}$ $7-\mathrm{c}: 10 \mathrm{~min}$

Photo. 7

Electron micrographs of two step replicas of films formed in $0.1 \mathrm{~N}$-ammonia bath $(\times 20,000)$.
る・

$$
\mathrm{Al}^{3+}+2 \mathrm{H}_{2} \mathrm{O} \rightarrow \mathrm{Al} \cdot \mathrm{O} \cdot \mathrm{OH}+3 \mathrm{H}^{+}
$$

したがって凹円面の発達状況から Boehmite の生長速 度の大小を推定しらる。

アンモニア水化成皮膜では，化成の最も初期から無数 に粒界のある平滑面となって战り，化成 5 分で山口面が 展開する.この浴では先きの浴の場合よりも Boehmite 生長がかなり速い，化成中の浴の $\mathrm{pH}$ 変化を測定すると， 次のよ5に降下し, 最終的には蒸留水浴と同様の $\mathrm{pH}$ 值 に到達する。

0 分: $\mathrm{pH}=11.2,10$ 分 : $\mathrm{pH}=10.3,20$ 分 : $\mathrm{pH}=9.5$ 30 分 : $\mathrm{pH}=8.8,40$ 分 : $\mathrm{pH}=7.8$

$\mathrm{OH}^{-}$の Boehmite 生成に対する役割を検討すると,
(1) Boehmite 生成過程の反忘物となっている((2)式).

$$
\mathrm{Al}^{3+}+2 \mathrm{OH}^{-} \rightarrow \mathrm{Al} \cdot \mathrm{O} \cdot \mathrm{OH}+\mathrm{H}^{+}
$$

(2) $\mathrm{Al}^{3+}$ 泳動を誘発するための強い電場を作るものであ る、すなわち金属表面には化成前からすでに薄膜（過渡 的な構造の酸化物) が付着している.したがって (2) 式 の Boehmite 生成の前に薄膜の溶解かまたは薄膜内人才 ン泳動功なければならない。このことは蒸留水とアンモ 二ア水の場合の化成速度の相違からも推定できる。陽極 酸化皮膜（Barrier 層）の場合は皮膜抵抗が非常に高い (Barrier 層を純 $\mathrm{Al}_{2} \mathrm{O}_{3}$ と仮定すると約 $1,200 \mathrm{M} \cdot \Omega \cdot \mathrm{cm}$, Wood $^{9\rangle}$ らの推定值では約 $\left.10 \mathrm{k} \Omega \cdot \mathrm{cm}\right)$ ために高電場を 与えるときにのみ Frenkel 型の格子久陷を生じ, 久陷 の移動と言ら方法でイオン泳動が可能となっており，そ
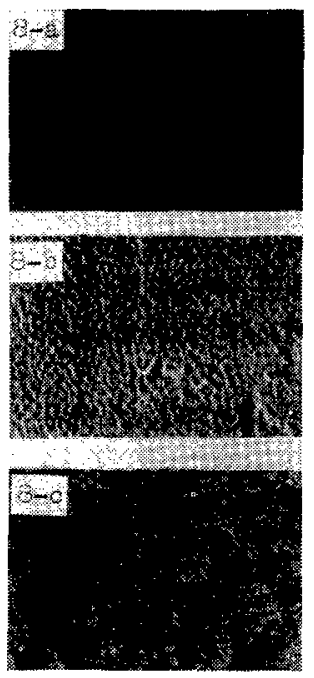

$8-\mathrm{a}: 1 \mathrm{~min}, 8-\mathrm{b}: 20 \mathrm{~min}$, $8-\mathrm{c}: 60 \mathrm{~min}$

\section{Photo. 8}

Electron micrographs of two step replicas of films formed in $0.1 \mathrm{~N}$ triethanolamin bath $(\times 20,000)$.
のときの印加電圧 $E$ とイオ

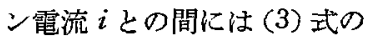
関係がある。

$i=i_{0} \exp \{-(W-q a E) / k T\}$

ところで今問題としている化 学化成においては, 高温化成 (温度 $95 \sim 100^{\circ} \mathrm{C}$ ) と言う熱工 ネルギー供給状態にあり，局 部アノードの $\mathrm{Al}^{3+}$ の活性化 と薄膜内の格子の乱れが起り やすい状態になっている、こ のときに薄膜表面に $\mathrm{OH}^{-}$吸 着層が形成されるならば，電 場が作られ $\mathrm{Al}^{3+}$ の溶液側一 の泳動はかなり容易になると 思われる。なお $\mathrm{OH}^{-}$の金属 側人の泳動は，そのイオン半 径が $\mathrm{Al}^{3+}$ よりも大きいため に酸化物格子中に入りにく $\therefore$, 全イオン泳動の一部を分 担するに過ぎいと思われ
る. (3) $\mathrm{OH}^{-}$の必要性はさらに，(2) 式に生成する $\mathrm{H}^{+}$ の中和にある ${ }^{\mathrm{a})}$. 生成物の $\mathrm{H}^{+}$は気体のように拡散が速 やかに行なわれないから, Boehmite 表面に吸着（また は接近して存在し，皮膜表面に proton space charge を作るとみられる。これは次の $\mathrm{Al}^{3+}$ 泳動に対してエネ ルギー障壁を作ることになる、したがっで（2）式の継続 には中和か溶液中への拡散による proton space charge の軽減が必要である。

Boehmite 生長の際の外観の変化をとめると， A (一様な平滑面) $\rightarrow$ B (無数の粒界で区分された平滑 面) $\rightarrow \mathrm{C}$ (複雑な凹凸面) となっている， B 段階から C 段階への移行は急速に起こり，Cは Boehmite の発達 した究極の面である、Boehmite の極端な生長は粒界の 
㫫出を発端としている. 今 Boehmite 生成の際の局部力 ソード側の挙動を考えると，(4) 式のように, $\mathrm{H}_{2} \mathrm{O}$ の解 離加らの $\mathrm{H}^{+}$の放電加推定される. Altenpohl ${ }^{111,12)}$,

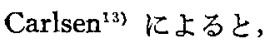

$$
\mathrm{H}^{\top}+e \rightarrow \mathrm{H} \rightarrow 1 / 2 \mathrm{H}_{2} \uparrow
$$

H は粒界を通って金属内に摭散し，その後再結合を行 なって泡状の水素となる．その際粒界にひび割れを作る から Boehmiteの生成は急速になると考えられている。 また Pryor ${ }^{14315)}$ によると，皮膜はカソード反応に对し て非常に大きな抵抗となるとされている。これらをあわ せると，(4) 式の過程注皮膜の不完全な粒界から始守 り，その生成物の水素ガスによ。て粒界が破壊される と，反忘は急激に速くなると解釈される.

トリエタノールアミン化成の場合性アンモニア水の場 合と同様に化成初期に B 段階が現かれる。しかし C 段 階へは進展しない点が特異である．先きの電子線回折か らも Boehmite の結晶性が特閒とともに劣化することが 示されている. したがて Boehmite 性生成後さらに溶解 されるように考えられる．アンモニア水化成との相違の 原因は一つに浴中の $\mathrm{OH}^{-}$濃度の時間的変化がアンモニ ア水の場合上逆の方向に移行することが挙げられる.す なわち化成開始時には雨浴上もほぼ同じ值の $\mathrm{pH}$ であ るがアンモニア水の方は $\mathrm{NH}_{3}$ の飛散によって中性側一 移行し、トリェタノールアミン液では水の蒸発によって $\mathrm{pH}$ が上昇して行く.最初の $\mathrm{pH}$ 值は Boehmite が穻 定な限界点に近いから， $\mathrm{pH}$ の中性側へのずれまたはア ルカリ側へのわずかなずれは大きな影響を与えることに なる.アンモニア水化成の場合注 Boehmite が安定で ありトリエタノールアミン化成の場合は不安定となり アルミの腐食現象が起きるのである、な扔両浴の相違に ついてはさらに陽イオンの影響を検㣙する必要がある。

\section{3 化成による重量変化}

Boehmite 生成の際の重量堌加率, $\mathrm{Al} \cdot \mathrm{O} \cdot \mathrm{OH} / \mathrm{Al}=2.2$ を基に試料の重量変化を比較すると，その過程が保讙皮 膜の生成であるかまたは腐食反応であるかがわかる。

Fig. 2 に示すように蒸留水化成の場合は生長が遅く,

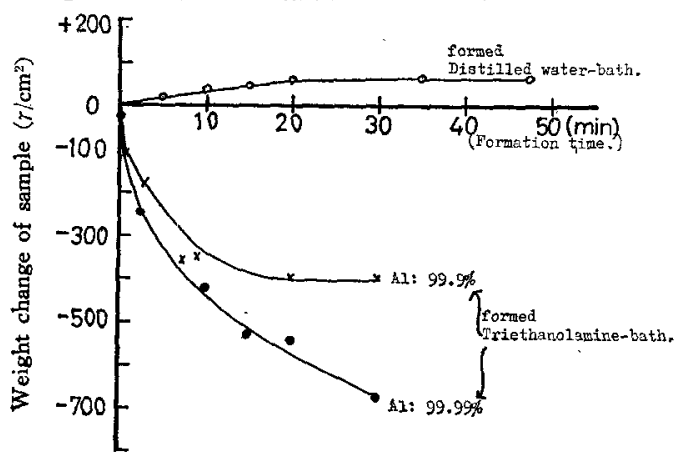

Fig. 2 Weight change of sample during boehmite forming process.

保護皮膜生成型である. これに対しトリェタノー ルアミン化成の場合は試 料重量がもとの值以下に 顕著核少する。っま り典型的な腐食反応であ る.

\section{$3.4 \mathrm{Al}^{3+}$ 溶出量}

トリエタノールアミン 浴に溶出する $\mathrm{Al}^{3+}$ 比 色分析によって測定し， 化成時間との関倸を示し た (Fig. 3).

\section{5 皮膜の等価回路}

皮膜の基本となる等価 回路注抵抗成分 $R$ と容

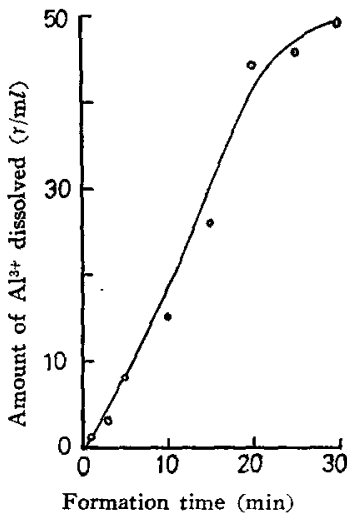

Fig. 3

Amount of $\mathrm{Al}^{\text {s+ }}$ against formation time in $0.1 \mathrm{~N}-$ triethonolamine bath.

量成分 $C$ とが並列にあると考える。このときのインピ 一ダンス $Z$ は $Z=R /(1+j \omega C R)$ である。

皮膜の実測抵抗成分 $R_{a}$ と実測容量成分 $C_{b}$ とは以下 に記すようにそれぞれ周波数に依存するものとなり，皮 膜が電気的に複雑な構造をなしていることが示された。

これまでの実験結果から，化成皮膜の構造を区分する と，結合のゆるい酸化物層加らなる外層部之結晶性酸化 物層からなる内層部に分けられる，また凹部と凸部（局 部カソードと局部アノードに対忘すると推定される)に 分けられる.したがって皮膜全体としては (A) のよう な等価回路が与えられる、ここで回路を簡略化すると， 外層部については比誘電率が低いと推定されることと層 が厚いと考元られることから $C_{a^{\prime}}, C_{c^{\prime}}$ が省略されらる。 また内層部については極く薄い層であるとの推定に上 り， $R_{a}, R_{c}$ が省略されらる.したがって (A) 惊 (B) の等価回路に簡学化し，その合成インピーダンス $Z_{g}$ は 次の内容となる。

$$
\begin{aligned}
1 / Z_{e}= & {\left[\omega^{2} C_{a}^{2} R_{a^{\prime}} /\left(\omega^{2} C_{a}^{2} R_{a^{\prime}}{ }^{2}+1\right)\right.} \\
& \left.+\omega^{2} C_{c}{ }^{2} R_{c^{\prime}} /\left(\omega^{2} C_{c}{ }^{2} R_{c^{\prime}}{ }^{2}+1\right)\right] \\
& +j \omega\left[C_{a} /\left(\omega^{2} C_{a}{ }^{2} R_{a^{\prime}}{ }^{2}+1\right)\right. \\
& \left.+C_{c} /\left(\omega^{2} C_{c}{ }^{2} R_{c^{\prime}}{ }^{2}+1\right)\right]
\end{aligned}
$$

実測値 $R_{b}, C_{b}$ 注試料を二枚対立させたときの值なの で， $R_{b}, C_{b}$ は (5) 式を 2 倍したものに相当する（(6) 式).

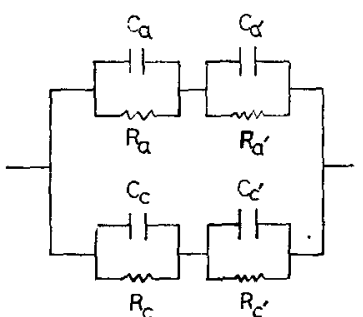

(A)

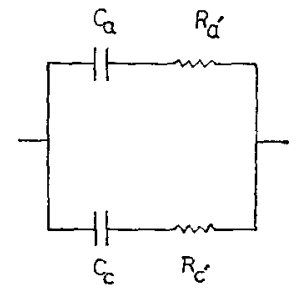

(B) 


$$
\left.\begin{array}{c}
R_{b}=2 /\left[\omega^{2} C_{a}{ }^{2} R_{a} /\left(\omega^{2} C_{a}{ }^{2} R_{a^{\prime}}{ }^{2}\right.\right. \\
\left.+1)+\omega^{2} C_{c}{ }^{2} R_{c^{\prime}}{ }^{2} /\left(\omega^{2} C_{c}{ }^{2} R_{c^{\prime}}{ }^{2}+1\right)\right] \\
C_{b}=(1 / 2)\left[C_{a} /\left(\omega^{2} C_{a}{ }^{2} R_{a^{\prime}}{ }^{2}+1\right)+C_{c} /\left(\omega^{2} C_{c}{ }^{2} R_{c^{\prime}}{ }^{2}+1\right)\right]
\end{array}\right\}
$$

ここで皮膜の電気的性質が $\omega^{2} C_{a}{ }^{2} R_{a^{\prime}}{ }^{2} \ll 1$, または， $\omega^{2} C_{c}{ }^{2} R_{c^{\prime}}{ }^{2} \ll 1$ の関係をもつならば，

$$
\left.\begin{array}{l}
R_{b} \doteqdot 2 / \omega^{2}\left(C_{a}{ }^{2} R_{a^{\prime}}+C_{c}{ }^{2} R_{c^{\prime}}\right) \\
C_{b} \doteqdot\left(C_{a}+C_{c}\right) / 2
\end{array}\right\}
$$

となり, $\omega^{2} C_{a}{ }^{2} R_{a^{\prime}}{ }^{2} \gg 1, \omega^{2} C_{c}^{2} R_{c^{\prime}}{ }^{2} \gg 1$ であれば,

$$
\left.\begin{array}{l}
R_{b} \doteqdot 2\left(R_{a^{\prime}}+R_{c^{\prime}}\right) \\
C_{b} \doteqdot\left(1 / 2 \omega^{2}\right)\left(1 / C_{a} R_{a^{\prime}}{ }^{2}+1 / C_{c} R_{c^{\prime}}{ }^{2}\right)
\end{array}\right\}
$$

となる. $R_{b}, C_{b}$ の周波数依存性を見ると皮膜が誘電体 的な物質であるかまたは非誘電体的な物質であるかが推 定できる.

3.5 .1 化成時間亡測定インピーダンスＦig. 4 は $1,000 \mathrm{c} / \mathrm{s}, 3 \%$ 酒石酸アンモン液中で測定したときの化 成時間とインピーダンス $\left(t-R_{b}\right.$, およぴ $\left.t-C_{b}\right)$ 曲線で ある。

化成 0 分のときは, $R_{b} \doteqdot 400 \Omega, C_{b} \doteqdot 1.2 \mu F$ とな り, 化成前汃ら金属表面にある薄膜についての值が得ら れた。

$t-R_{b}$ と $t-C_{b}$ 曲線は化成浴によってまったく違っ た形になり，Boehmite 生長過程が化成浴によって異な

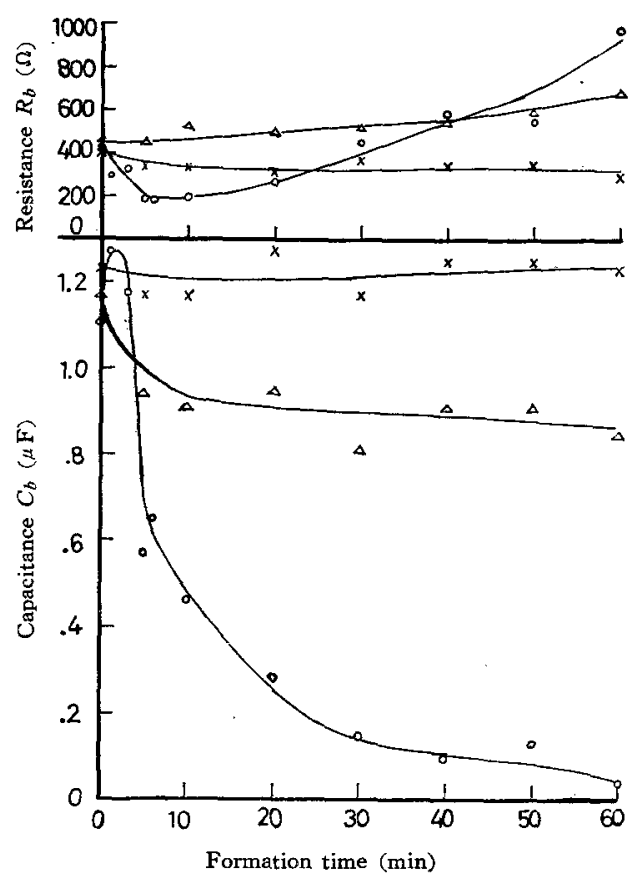

(measured in $3 \%$ ammonium tartrate solution, $25^{\circ} \mathrm{C}, 1,000 \mathrm{c} / \mathrm{s}$ )

$-\triangle-$ : formed in distilled water

-O- : formed in $0.1 \mathrm{~N}$-ammonia

$-\times-$ : formed in $0.1 \mathrm{~N}$-triethanolamine

Fig. 4 Relation between formation time and impedance.
ることが裏づけられた.

本研究の試料 (アルミ線) のよ5な同心円简形のコン デンサーでは容量 $C$ は (9) 式で表わされる.

$$
\begin{aligned}
C & =2 \pi \varepsilon_{0} / \log (a+d / a) \\
& \div 2 \pi \varepsilon_{0} \cdot a / d
\end{aligned}
$$

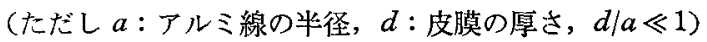
したがって $1 / C$ の変化から膜厚 $d$ の增減が観測され る. しかし測定される表面積が変化するときはこの関俰 は成立しない，Boehmite が著しく発達した面では凹凹 が生じ総表面積が増加してくるから，前段階とそのまま 比較することはできない。

3.5.2 皮膜の周波数依在性 化成前から金属面にあ る薄膜に関しては, $R_{b}$ 成分は周波数に強く依存し $C_{b}$ 成分はあまり依存しない（Fig． $5,6,7)$.このこと溥 膜が (7) 式型の举動すなわち誘電体に近い物質であるこ とを示している，薄膜の厚さを概算してみると次のよう になる.すなわち薄膜について得られた $C_{b}$ 注二枚極の 合計量となっているから, 一試料の容量 $C_{e}$ は $C_{e}=C_{b}$ $\times 2=1.2 \times 2=2.4 \mu \mathrm{F}$ である. これを $1 \mathrm{~cm}^{2}$ 当たりの 偪に直すと $C_{e, 0}=C_{e} \times 2=4.8 \mu \mathrm{F}$ となる. 今, 薄膜の

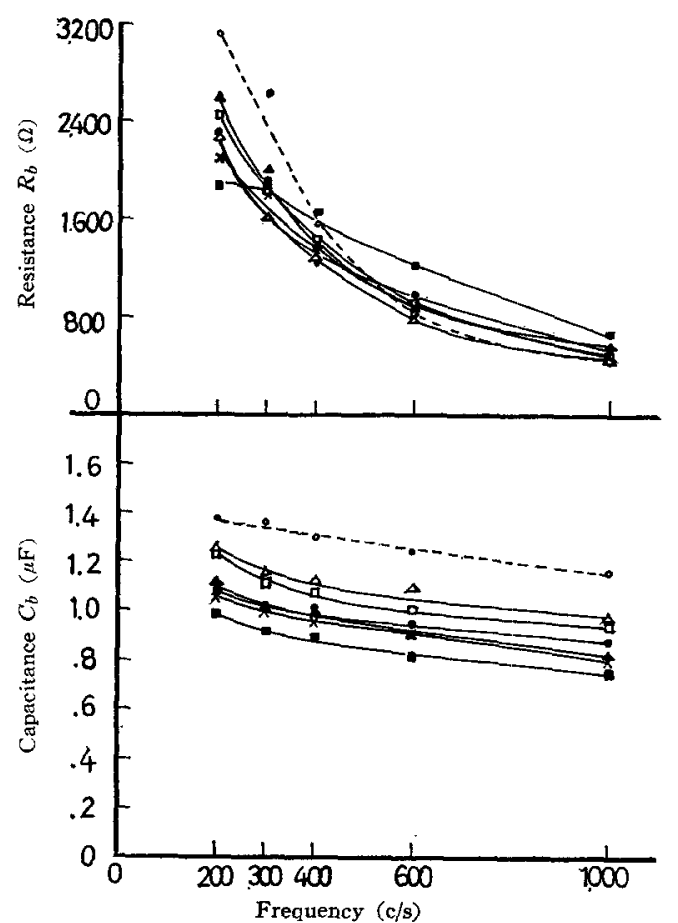

(measured in $3 \%$-ammonium tartrate solution, $25^{\circ} \mathrm{C}, 1,000 \mathrm{c} / \mathrm{s}$ ) $-\cdots---: 0 \mathrm{~min}$ (immediately after pretreated)

$-\triangle-: 10 \mathrm{~min},-\square-: 20 \mathrm{~min},-\times-: 30 \mathrm{~min}$

- - : $40 \mathrm{~min},-\Delta-: 50 \mathrm{~min},-\mathbf{-}-: 60 \mathrm{~min}$

Fig. 5 Frequency dependence of balancing parallel resistance, $R_{b}$ capacitance, $C_{b}$, for films formed for various times in distilled water bath. 


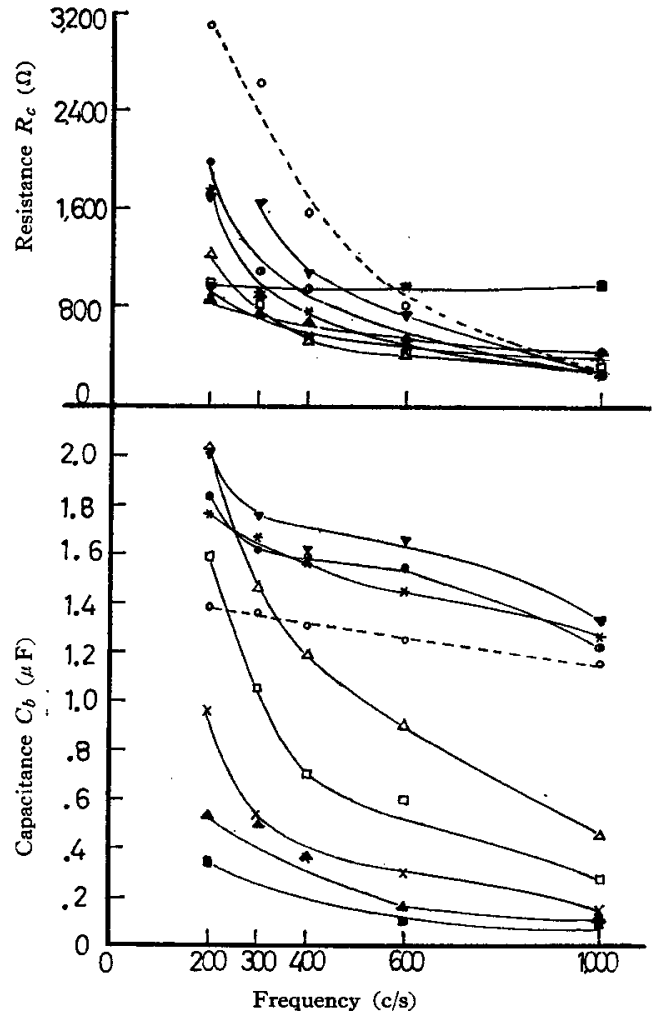

(measured in $3 \%$-ammonium tartrate solution, $25^{\circ} \mathrm{C}, 1,000 \mathrm{c} / \mathrm{s}$ )

$$
\begin{aligned}
& --O--: 0 \mathrm{~min} \text { (immediately after pretreated) } \\
& -*-: 0.5 \mathrm{~min},-\nabla-: 1.5 \mathrm{~min},-\square-: 3 \mathrm{~min} \\
& -\triangle-: 10 \mathrm{~min},-\square-: 20 \mathrm{~min},-\times-: 30 \mathrm{~min} \\
& -\Delta-: 50 \mathrm{~min},-\square-: 60 \mathrm{~min}
\end{aligned}
$$

Fig. 6 Frequency dependence of balancing parallel resistance, $R_{b}$ capacitance, $C_{b}$, for films formed for various times in $0.1 \mathrm{~N}$-ammonia bath.

固有容量 $C_{s}$ (表面積 $1 \mathrm{~cm}^{2}$, 厚さ $1 \AA$ のときの容量) として無定形の $\mathrm{Al}_{2} \mathrm{O}_{3}$ について得られている值 $C_{s}=94$ $\mu \mathrm{F}^{9)}$ を代用するならば， $d=94 / 4.8 \div 20 \AA$ として薄膜 の厚さが求められる.薄膜の真の表面積がみかけの面積 と異なる場合注 roughness factor $n$ を関与させねばな らない.このとき $d$ は $d=94 /(4.8 / n)=20 \times n \AA$ とな る. 実際は roughness factor は $10>n>1^{16)}$ の範囲 にあると考えられる。

蒸留水化成皮膜の周波数依存性は上記の薄膜の場合上 同様の挙動が得られた．皮膜は (7) 式型すなわち誘電体 型である. 測定值 $C_{b}$ 中には roughness factor の増加 の㟢与が当然含まれているから，化成時間と皮膜増加量 との関係を求めることはできない，

アンモニア水化成皮膜の場合法, 周波数依存性が化成 途上で変化する。第一の型は化成初期に見られる (Fig. 4 亿おいて観察すると $C_{b}$ が急上异する時期であり, 化 成 $0 \sim 3$ 分の間を指す). 第一型の $R_{b}$ 注周波数に强く

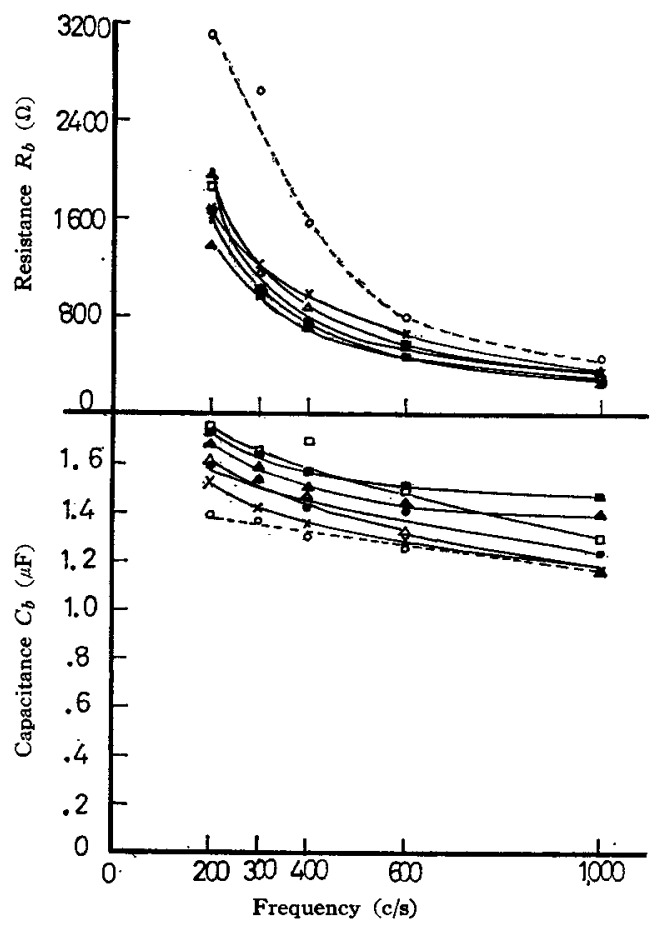

(measured in $3 \%$-ammonium tartrate solution, $25^{\circ} \mathrm{C}, 1,000 \mathrm{c} / \mathrm{s}$ ) -- $-\mathrm{O}^{---: 0} 0 \mathrm{~min}$ (immediately after pretreated) $-\triangle-: 10 \mathrm{~min},-\square-: 20 \mathrm{~min},-\times-: 30 \mathrm{~min}$

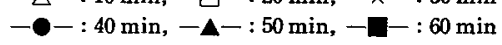

Fig. 7 Frequency dependence of balancing parallel resistance, $R_{b}$ capacitance, $C_{b}$ for films formed for various times in $0.1 \mathrm{~N}$-triethanolamine bath.

依存し， $C_{b}$ はあまり依存しない.すなわちこの䟢の皮 膜は (7) 式型であり誘電体的である. $\mathrm{C}_{b}$ が化成時間と ともに増大するのは roughness factor の増加によるも のと考えられる. 第二の型は化成 3 分以降において見ら れる (Fig. 4 においては $C_{b}$ が化成時間とともに急激に 減少する時期を指す). 第二の型は第一の型と傾向が逆 で, $R_{b}$ があまり変化せず, $C_{b}$ が周波数とともに変化す る.すなわち (8) 式型である. 以上のように皮膜は化成 途上で性質が (7) 式型から (8) 式型に変化する. 皮膜の 性質が变化する時点（化成約 3 分）は電子顕微鏡では凹 凸面が確認される時期となっている．第二の型において $C_{b}$ と化成時間との関倸が時間の増加とともに $C_{b}$ が急 激に減少するのは, 比誘電率の減少と非常に大きな膜厚 の増加があるためと考えられる。すなわち第二の型に移 行したとき皮膜は電導型となり結合のゆるい酸化物が多 量に生ずるものと考えられる.

トリエタノールアミン化成皮膜の場合は, $R_{b}, C_{b}$ はそ れぞれ，やや増大または減少する．周波数依存性はどの 時間をとっても大体同じような傾向を示す．これは（7) 式に似ているが，化成によって $C_{b}$ がやや大きくなる点 
に特色がある. 蒸留水化成皮膜のときも薄膜と同じよ5 な挙動となったが, $C_{b}$ は化成によって減少していた. 電 子線回折や皮膜溶解量の測定結果などをあわせると，卜 リエタノールアミン化成の場合は, 皮膜の生成と溶解が 直結していて，皮膜の蓄積は起こらないものと解燔され る.ことばをかえれば，アルミの腐食が起きているので あり，その過程の途中に酸化物的なものになる時期があ ると見ることができる. 化成により $C_{b}$ がやや增大寸る のは roughness factor の增大によるものと考えられる.

\section{4 結 論}

水との反応による化学化成皮膜においては，金属/酸 化物溶液間に作用する「局部的」(すなわち局部アノー ドに作用する）電場によってイオンの皮膜内泳動が起き その結果 Boehmite が生長すると考えられらる. 皮膜内 泳動は Boehmite 生成において先行過程となっている。

浴中の $\mathrm{OH}^{-}$濃度は次のように Boehmite の生成と密接 な関倸があると考えられる. (1) $\mathrm{Al}^{3+}+2 \mathrm{OH}^{-} \rightarrow \mathrm{Al} \cdot \mathrm{O}$. $\mathrm{OH}+\mathrm{H}^{+}$の過程の反応物である，(2) $\mathrm{Al}^{3+}$ の皮膜内泳 動を誘発する(強い電場を作る) 荷電粒子である, (3) 生成した $\mathrm{H}^{+}$を中和し次の Boehmite 生成を起こすふ んい気を作る. しかし多量の $\mathrm{OH}^{-}$は Boehmite を简食 させる原因となるためその量に恃限界が設けられる、ア ンモニア水は化成初期に適度の $\mathrm{OH}^{-}$量を含み, 速い皮 膜生成を可能にし，化成とともに $\mathrm{NH}_{3}$ が飛散すること により Boehmite の不安定化を防ぐ，したがって最も良 い化成浴と言うことができる.

Boehmite 表面注生長に伴い, 平滑面 $\rightarrow$ 無数に粓界の ある平滑面 $\rightarrow$ 凹凸面へと変形する. 凹凸面は体積増加 によって作られたものである.この凹凸面の生ずる直前 に粒界が顕著になる時期がある. 粒界は, カソード反応 $\left(\mathrm{H}^{+}+e \rightarrow \mathrm{H} \rightarrow 1 / 2 \mathrm{H}_{2} \uparrow\right)$ が起こる個所であり， $\mathrm{H}_{2}$ 発
生によって皮膜粒界が破かいされるために粒界がめいり 上う化すると思われる. カソード反応は皮膜の存在下で は起こりにくく, Boehmite 生成過程を律速していると 考えられる.

な衫補足的には皮膜外観の観察法としてはく離皮膜法 は好ましくないとの結論を得た。

終わりに電子線回折に対して有益なご助言を戴いた東京都立 大学工学部助教授田辺良美氏, 並びに本研究に対してご支援を 賜わった財团法人軽金属奖学会（大阪）に厚く樈意を表する.

(Received Oct. 11 1967)

\section{文献}

1) D.G. Altenpohl, Corrosion Engineering, 12, No. I (1963).

2) K. Yamamoto, N. Baba, S. Tajima, Proc. 2nd European Symposium on Corrosion Inhibitor: (Ferrara, Italy) 777 (1965).

3）山本克宗，馬場宣良，田島 栄，第 14 回篦食防食討論会にて請演 (1967).

4) M.J. Pryor, D.S. Keir, J. Electrochem. Soc. 102, 370, (1955).

5) 分析化学講座 1-B, 比色分析法 I. 共立出版 75 (1956).

6) J.H. de Boer et al, "Reactivity of Solids", 317 (1961), Elsevier.

7) A. Domony, E. Lichtenberger-Bajza, Metalloberfläche 15, 134 (1964).

8) R.K. Hart, Trans. Faraday Soc. 53, 1020 (1957).

9) T.P.Hoar, G.C. Wood, Electrochimica Acta, 7, 333 (1962).

10) J.F. Murphy, "Proceedings of International Symposium on Anodizing" Extended Abstracts in Birmingham, April (1967).

11) D. Altenpohl, Z. Metallkunde 48, 306 (1957).

12) D. Altenpohl, Aluminium, 33, 306 (1957).

13) K.M. Carlsen, J. Electrochem. Soc. 104, 147 (1957)

14) M.J. Pryor, D.S. Keir, J. Electrochem. Soc. 102, 605 (1955).

15) M.J. Pryor, Z. Elektrochem. 62, 782 (1958).

16）馬埸宣良, 田島栄, 電気化学協会第 34 回大会心七講演。

17) T.P. Hoar, J. Yahalom, J. Electrochem. Soc. 110, 614 (1963).

18) A.F. Beck, M.A. Heine, D.S. Keir, D. van Rooyen, M.J. Pryor, Corrosion Science 2, 133 (1962). 